TOXIC SUBSTANCES HYDROLOGY PROGRAM

Prepared in cooperation with the

AIR FORCE CENTER FOR ENGINEERING AND THE ENVIRONMENT

Groundwater-Quality Data for a Treated-Wastewater Plume near the Massachusetts Military Reservation, Ashumet Valley, Cape Cod, Massachusetts, 2006-08

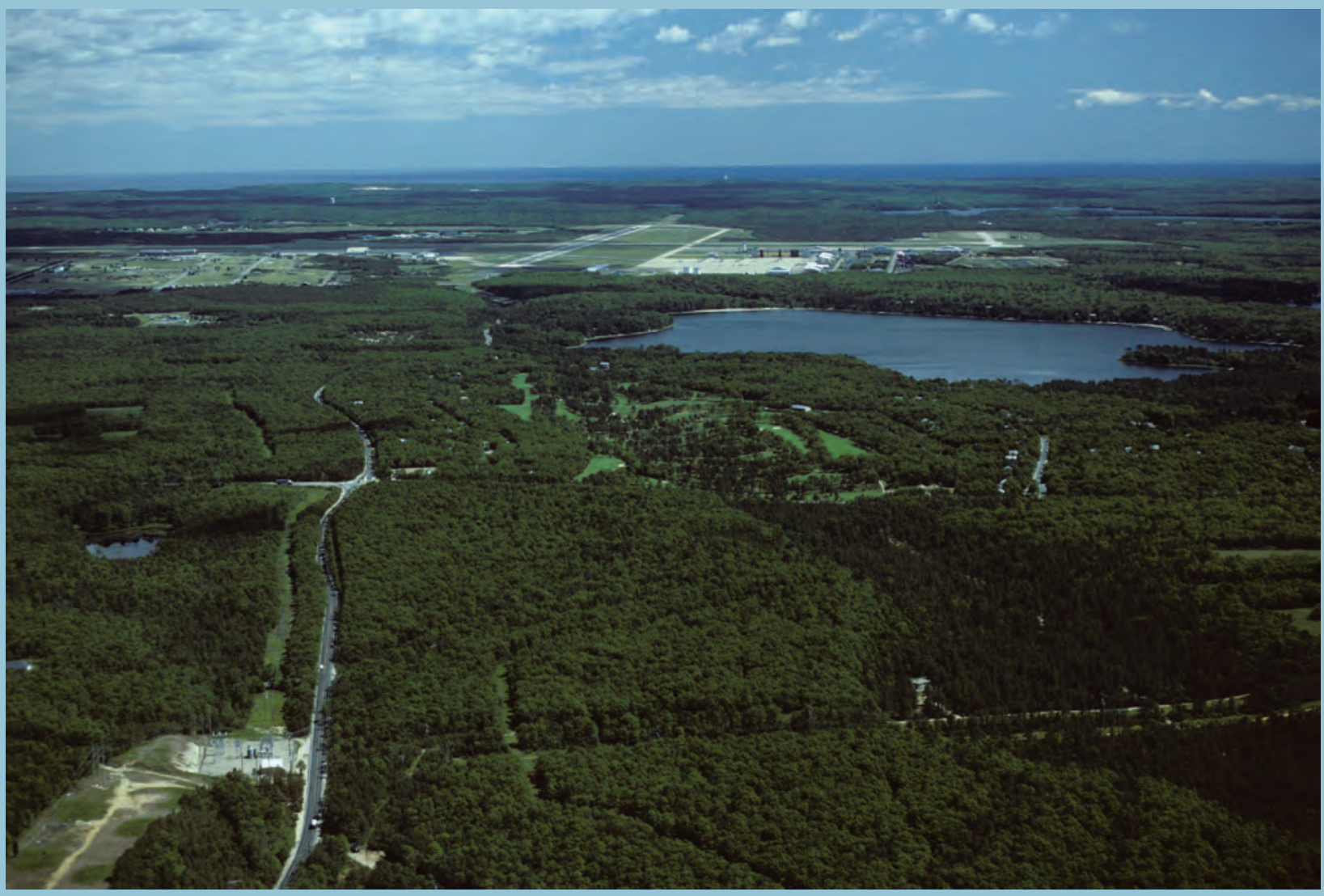

Data Series 648 
Cover. Northward view of the Ashumet Valley on western Cape Cod, Massachusetts. The valley is distinguishable by the dark green trees and the central part of the golf-course fairways. Ashumet Pond is in the center right of the photo, and Cape Cod Bay is visible in the far distance at the top of the photo. Airfield runways of the Massachusetts Military Reservation can be seen between the bay and the pond. Photograph by Denis R. LeBlanc, USGS, 1984. 


\section{Groundwater-Quality Data for a Treated-Wastewater Plume near the Massachusetts Military Reservation, Ashumet Valley, Cape Cod, Massachusetts, 2006-08}

By Jennifer G. Savoie, Denis R. LeBlanc, Gillian M. Fairchild, Richard L. Smith, Douglas B. Kent, Larry B. Barber, Deborah A. Repert, Charles P. Hart, Steffanie H. Keefe, and Luke A. Parsons

Prepared in cooperation with the

Air Force Center For Engineering and the Environment

Data Series 648 


\section{U.S. Department of the Interior \\ KEN SALAZAR, Secretary \\ U.S. Geological Survey \\ Marcia K. McNutt, Director}

\section{U.S. Geological Survey, Reston, Virginia: 2012}

For more information on the USGS - the Federal source for science about the Earth, its natural and living resources, natural hazards, and the environment, visit http://www.usgs.gov or call 1-888-ASK-USGS

For an overview of USGS information products, including maps, imagery, and publications, visit http://www.usgs.gov/ pubprod

To order this and other USGS information products, visit http://store.usgs.gov

Any use of trade, product, or firm names is for descriptive purposes only and does not imply endorsement by the U.S. Government.

Although this report is in the public domain, permission must be secured from the individual copyright owners to reproduce any copyrighted materials contained within this report.

Suggested citation:

Savoie, J.G., LeBlanc, D.R., Fairchild, G.M., Smith, R.L., Kent, D.B., Barber, L.B., Repert, D.A., Hart, C.P., Keefe, S.H., and Parsons, L.A., 2012, Groundwater-quality data for a treated-wastewater plume near the Massachusetts Military Reservation, Ashumet Valley, Cape Cod, Massachusetts, 2006-08: U.S. Geological Survey Data Series 648, 11 p., CD-ROM. (Also available at http://pubs.usgs.gov/ds/648) 


\section{Contents}

Abstract
Introduction
Monitoring Groundwater Quality in the Treated-Wastewater Plume
Monitoring Wellss
Multilevel Samplers
Sample Collection from Wells and Multilevel Samplers
Field Water-Quality Measurements
Sample Preservation and Chemical Analysis
Summary.

\section{Figures}

1. Map showing the study area with the locations of monitoring wells, multilevel samplers, and profile borings sampled in 2006-08, and the extent of the treated-wastewater plume in 2007, Ashumet Valley, Cape Cod, Massachusetts .............2

2. Map showing the portion of the study area extending from the wastewater-disposal beds at the Massachusetts Military Reservation to Ashumet Pond; the locations of monitoring wells, multilevel samplers, and profile borings sampled in 2006-08; and the extent of the treated-wastewater plume in 2007, Ashumet Valley, Cape Cod, Massachusetts.

3. Map showing the portion of the study area extending from Ashumet Pond to Route 28; the locations of monitoring wells, multilevel samplers, and profile borings sampled in 2006-08; and the extent of the treated-wastewater plume in 2007, Ashumet Valley, Cape Cod, Massachusetts

\section{Tables}

1. Location coordinates, land-surface and screen altitudes, well diameters, casing and screen materials, and water-level altitudes and measurement dates for monitoring wells, Ashumet Valley treated-wastewater plume, Cape Cod, Massachusetts [Click here].

2 Location coordinates, land-surface and screen altitudes, and estimated water-table altitudes for multilevel samplers, Ashumet Valley treated-wastewater plume, Cape Cod, Massachusetts [Click here].

3 Drilling method, location coordinates, altitudes of land surface and tops and bottoms of sampling intervals, and estimated altitudes of the water table for direct-push and sonic profile borings, Ashumet Valley treated-wastewater plume, Cape Cod, Massachusetts, 2006-08 [Click here].

4 Field water-quality analyses for groundwater samples collected from wells and multilevel samplers, Ashumet Valley treated-wastewater plume, Cape Cod, Massachusetts, 2007 [Click here]. 
5 Concentrations of selected anions, ammonium, and nitrous oxide in groundwater samples collected from wells and multilevel samplers, Ashumet Valley treated-wastewater plume, Cape Cod, Massachusetts, 2007 [Click here]

6 Ultraviolet/visible light absorbance and concentrations of dissolved organic carbon and methylene blue active substances in groundwater samples collected from wells and multilevel samplers, Ashumet Valley treated-wastewater plume, Cape Cod, Massachusetts, 2007 [Click here].

7 Concentrations of selected inorganic solutes, including cations, anions, and minor elements, in groundwater samples collected from wells and multilevel samplers, Ashumet Valley treated-wastewater plume, Cape Cod, Massachusetts, 2007 [Click here]

8 Field water-quality analyses for groundwater samples collected from direct-push and sonic profile borings, Ashumet Valley treated-wastewater plume, Cape Cod, Massachusetts, 2006-08 [Click here].

9 Concentrations of selected anions and ammonium in groundwater samples collected from direct-push and sonic profile borings, Ashumet Valley treated-wastewater plume, Cape Cod, Massachusetts, 2006-08 [Click here].

10. Concentrations of selected inorganic solutes, including cations, anions, and minor elements, in groundwater samples collected from direct-push and sonic profile borings, Ashumet Valley treated-wastewater plume, Cape Cod, Massachusetts, 2006-08 [Click here]. 


\section{Conversion Factors, Data, and Abbreviations}

\begin{tabular}{|c|c|c|}
\hline Multiply & By & To obtain \\
\hline \multicolumn{3}{|c|}{ Length } \\
\hline inch (in.) & 2.54 & centimeter $(\mathrm{cm})$ \\
\hline inch (in.) & 25.4 & millimeter (mm) \\
\hline foot (ft) & 0.3048 & meter $(\mathrm{m})$ \\
\hline liter (L) & 0.2642 & gallon (gal) \\
\hline mile (mi) & 1.609 & kilometer $(\mathrm{km})$ \\
\hline \multicolumn{3}{|c|}{ Area } \\
\hline square inch $\left(\right.$ in $\left.^{2}\right)$ & 6.452 & square centimeter $\left(\mathrm{cm}^{2}\right)$ \\
\hline \multicolumn{3}{|c|}{ Flow rate } \\
\hline gallon per minute (gal/min) & 0.06309 & liter per second $(\mathrm{L} / \mathrm{s})$ \\
\hline \multicolumn{3}{|c|}{ Concentrations of Chemical Constituents } \\
\hline Aluminum $[\mathrm{Al}](\mu \mathrm{M})$ & 26.98 & Aluminum $[\mathrm{Al}](\mu \mathrm{g} / \mathrm{L})$ \\
\hline Ammonium $\left[\mathrm{NH}_{4}\right](\mu \mathrm{M})$ & 14.01 & Ammonium $\left[\mathrm{NH}_{4}\right](\mu \mathrm{g} / \mathrm{L})$ \\
\hline Arsenic $[\mathrm{As}](\mu \mathrm{M})$ & 74.92 & Arsenic $[\mathrm{As}](\mu \mathrm{g} / \mathrm{L})$ \\
\hline Barium $[\mathrm{Ba}](\mu \mathrm{M})$ & 137.3 & Barium $[\mathrm{Ba}](\mu \mathrm{g} / \mathrm{L})$ \\
\hline Boron $[\mathrm{B}](\mu \mathrm{M})$ & 10.81 & Boron $[\mathrm{B}](\mu \mathrm{g} / \mathrm{L})$ \\
\hline Cadmium $[\mathrm{Cd}](\mu \mathrm{M})$ & 112.4 & Cadmium $[\mathrm{Cd}](\mu \mathrm{g} / \mathrm{L})$ \\
\hline Calcium $[\mathrm{Ca}](\mu \mathrm{M})$ & 40.08 & Calcium $[\mathrm{Ca}](\mu \mathrm{g} / \mathrm{L})$ \\
\hline Carbon, organic, dissolved $[\mathrm{DOC}](\mu \mathrm{M})$ & 12.01 & Carbon, organic, dissolved [DOC] $(\mu \mathrm{g} / \mathrm{L})$ \\
\hline Chloride $[\mathrm{Cl}](\mu \mathrm{M})$ & 35.45 & Chloride $[\mathrm{Cl}](\mu \mathrm{g} / \mathrm{L})$ \\
\hline Cobalt $[\mathrm{Co}](\mu \mathrm{M})$ & 58.93 & Cobalt $[\mathrm{Co}](\mu \mathrm{g} / \mathrm{L})$ \\
\hline Copper $[\mathrm{Cu}](\mu \mathrm{M})$ & 63.54 & Copper $[\mathrm{Cu}](\mu \mathrm{g} / \mathrm{L})$ \\
\hline Iron $[\mathrm{Fe}](\mu \mathrm{M})$ & 55.85 & Iron $[\mathrm{Fe}](\mu \mathrm{g} / \mathrm{L})$ \\
\hline Magnesium $[\mathrm{Mg}](\mu \mathrm{M})$ & 24.31 & Magnesium $[\mathrm{Mg}](\mu \mathrm{g} / \mathrm{L})$ \\
\hline Manganese $[\mathrm{Mn}](\mu \mathrm{M})$ & 54.94 & Manganese [Mn] $(\mu \mathrm{g} / \mathrm{L})$ \\
\hline Nickel $[\mathrm{Ni}](\mu \mathrm{M})$ & 58.71 & Nickel $[N i](\mu \mathrm{g} / \mathrm{L})$ \\
\hline Nitrate $\left[\mathrm{NO}_{3}\right](\mu \mathrm{M})$ & 14.01 & Nitrate $\left[\mathrm{NO}_{3}\right.$ as $\left.\mathrm{N}\right](\mu \mathrm{g} / \mathrm{L})$ \\
\hline Nitrite $\left[\mathrm{NO}_{2}\right](\mu \mathrm{M})$ & 14.01 & Nitrite $\left[\mathrm{NO}_{2}\right.$ as $\left.\mathrm{N}\right](\mu \mathrm{g} / \mathrm{L})$ \\
\hline Nitrous oxide $\left[\mathrm{N}_{2} \mathrm{O}\right](\mu \mathrm{M})$ & 28.02 & Nitrous oxide $\left[\mathrm{N}_{2} \mathrm{O}\right.$ as $\left.\mathrm{N}\right](\mu \mathrm{g} / \mathrm{L})$ \\
\hline Oxygen, dissolved $\left[\mathrm{O}_{2}\right](\mu \mathrm{M})$ & .03200 & Oxygen, dissolved $\left[\mathrm{O}_{2}\right](\mathrm{mg} / \mathrm{L})$ \\
\hline Phosphate $\left[\mathrm{PO}_{4}\right](\mu \mathrm{M})$ & .03097 & Phosphate $\left[\mathrm{PO}_{4}\right.$ as $\left.\mathrm{P}\right](\mathrm{mg} / \mathrm{L})$ \\
\hline Phosphorus [P] ( $\mu \mathrm{M})$ & 30.97 & Phosphorus $[\mathrm{P}](\mu \mathrm{g} / \mathrm{L})$ \\
\hline Potassium $[\mathrm{K}](\mu \mathrm{M})$ & 39.10 & Potassium $[\mathrm{K}](\mu \mathrm{g} / \mathrm{L})$ \\
\hline Silicon $[\mathrm{Si}](\mu \mathrm{M})$ & 28.09 & Silicon $[\mathrm{Si}](\mu \mathrm{g} / \mathrm{L})$ \\
\hline Sodium $[\mathrm{Na}](\mu \mathrm{M})$ & 22.98 & Sodium $[\mathrm{Na}](\mu \mathrm{g} / \mathrm{L})$ \\
\hline Strontium $[\mathrm{Sr}](\mu \mathrm{M})$ & 87.62 & Strontium $[\mathrm{Sr}](\mu \mathrm{g} / \mathrm{L})$ \\
\hline Sulfate $\left[\mathrm{SO}_{4}\right](\mu \mathrm{M})$ & 96.06 & Sulfate $\left[\mathrm{SO}_{4}\right](\mu \mathrm{g} / \mathrm{L})$ \\
\hline Zinc $[\mathrm{Zn}](\mu \mathrm{M})$ & 65.37 & $\operatorname{Zinc}[\mathrm{Zn}](\mu \mathrm{g} / \mathrm{L})$ \\
\hline
\end{tabular}


Temperature in degrees Celsius $\left({ }^{\circ} \mathrm{C}\right)$ may be converted to degrees Fahrenheit $\left({ }^{\circ} \mathrm{F}\right)$ as follows:

$$
{ }^{\circ} \mathrm{F}=\left(1.8 x^{\circ} \mathrm{C}\right)+32
$$

Vertical coordinate information is referenced to the National Geodetic Vertical Datum of 1929 (NGVD29).

Horizontal coordinate information is referenced to the North American Datum of 1927 (NAD27).

Altitude, as used in this report, refers to distance above the vertical datum.

Specific conductance is given in microsiemens per centimeter at 25 degrees Celsius $\left(\mu \mathrm{S} / \mathrm{cm}\right.$ at $\left.25^{\circ} \mathrm{C}\right)$.

Concentrations of chemical constituents in water are given in milligrams per liter (mg/L) or micromoles per liter $(\mu \mathrm{M})$.

\section{Acronyms}

AFCEE Air Force Center for Engineering and the Environment

BOD Biological oxygen demand

DOC Dissolved organic carbon

MBAS Methylene blue active substances

MMR Massachusetts Military Reservation

MLS Multilevel sampler

PVC Polyvinyl chloride

SPEIM System performance and ecological impact monitoring

USGS U.S. Geological Survey 


\section{Acknowledgments}

We thank Jonathan Davis and Rose Forbes of the Air Force Center for Engineering and the Environment (AFCEE); and Kurt Lyons, Mark Gifford, Dion Cruz, Kasey Rink, Matthew Greenberg, Amanda Young, Robert Buker, and their colleagues at HydroGeologic, Inc., CH2M Hill, Inc., and Boart Longyear, Inc., for helping to plan and organize the field work and collect the samples. A special thanks is due to Michelle Leab of CH2M Hill, Inc., and Brett Dubner of HydroGeologic, Inc., for their contributions to all aspects of this collaborative effort.

The authors also thank Jeffrey Barbaro, Andrew Massey, Timothy McCobb, and Larissa Cupp of the USGS for their help in collecting and analyzing the water samples. 
This page has been left blank intentionally. 


\title{
Groundwater-Quality Data for a Treated-Wastewater Plume near the Massachusetts Military Reservation, Ashumet Valley, Cape Cod, Massachusetts, 2006-08
}

\author{
By Jennifer G. Savoie, Denis R. LeBlanc, Gillian M. Fairchild, Richard L. Smith, Douglas B. Kent, Larry B. \\ Barber, Deborah A. Repert, Charles P. Hart, Steffanie H. Keefe, and Luke A. Parsons
}

\begin{abstract}
A plume of contaminated groundwater extends from former disposal beds at the Massachusetts Military Reservation's wastewater-treatment plant toward Ashumet Pond, coastal ponds, and Vineyard Sound, Cape Cod, Massachusetts. Treated sewage-derived wastewater was discharged to the rapid-infiltration beds for nearly 60 years before the disposal site was moved to a different location in December 1995.

Water-quality samples were collected from monitoring wells, multilevel samplers, and profile borings to characterize the nature and extent of the contaminated groundwater and to observe the water-quality changes after the wastewater disposal ceased. Data are presented here for water samples collected in 2007 from 394 wells (at 121 well-cluster locations) and 780 multilevel-sampler ports (at 42 locations) and in 2006-08 at 306 depth intervals in profile borings (at 20 locations) in and near the treated-wastewater plume. Analyses of these water samples for field parameters (specific conductance, $\mathrm{pH}$, dissolved oxygen and phosphate concentrations, and alkalinity); absorbance of ultraviolet/ visible light; and concentrations of nitrous oxide, dissolved organic carbon, methylene blue active substances, selected anions and nutrients, including nitrate and ammonium, and selected inorganic solutes, including cations, anions, and minor elements, are presented in tabular format. The natural restoration of the sand and gravel aquifer after removal of the treated-wastewater source, along with interpretations of the water quality in the treated-wastewater plume, have been documented in several published reports that are listed in the references.
\end{abstract}

\section{Introduction}

Treated wastewater was discharged to rapid-infiltration beds at the Massachusetts Military Reservation's (MMR) wastewater-treatment plant on Cape Cod for nearly 60 years before the disposal site was moved to a different location in December 1995. The disposal created a plume of contaminated groundwater that extends southward in the glacial sand and gravel aquifer (LeBlanc and others, 1986) from the former disposal site toward Ashumet Pond, coastal ponds, and Vineyard Sound approximately along the alignment of a topographic feature known locally as the Ashumet Valley. The plume, which was first described by LeBlanc (1984), is about 5 miles (mi) long, $0.6-1.0 \mathrm{mi}$ wide, and 100 feet (ft) thick (fig. 1), as generally defined by concentrations of nitrate-nitrogen, chloride, and boron greater than about 29, 170, and 0.56 micromoles per liter $(\mu \mathrm{M})$ $(0.4,6.0$, and 0.006 milligrams per liter $(\mathrm{mg} / \mathrm{L}))$, respectively, in 2007 (J.R. Barbaro, U.S. Geological Survey, written commun., 2010). These concentration thresholds are based on previous studies of groundwater quality on western Cape Cod (LeBlanc, 1984; Frimpter and Gay, 1979; and citations below). The plume of wastewater-contaminated groundwater is composed of a complex mixture of inorganic and organic solutes typical of treated sewage-derived wastewater (Barber, 1998; Barber and others, 1988; Barber and others, 2009; Böhlke and others, 2006; Ceazan and others, 1989; Field and others, 1992; Kent and others, 2000; Kent and Fox, 2004; Kent and Maeder, 1999; LeBlanc, 1984; McCobb and others, 2003; Parkhurst and others, 2003; Repert and others, 2006; Stollenwerk, 1996; Thurman and others, 1986; and Walter and others, 1996). The plume supports a microbial ecosystem that includes bacteria and protozoa (Harvey and Barber, 1992; Harvey and George, 1987; Harvey and others, 1984; Kinner and others, 2002; Kinner and others, 1997; Kinner and others, 1998; and Metge and others, 1993) and has well developed biogeochemical zones (Abrams and Loague, 2000; Abrams and others, 1998; Kent and others, 1994; LeBlanc and others, 1999; Lee and Bennett, 1998; Smith and Duff, 1988; Smith and others, 2004; Smith and others, 1991a; Smith and others, 1991b). Volatile organic compounds that were released from a former fire-training area near the wastewater-treatment plant also are in the plume (Air Force Center for Environmental Excellence, 2005). 


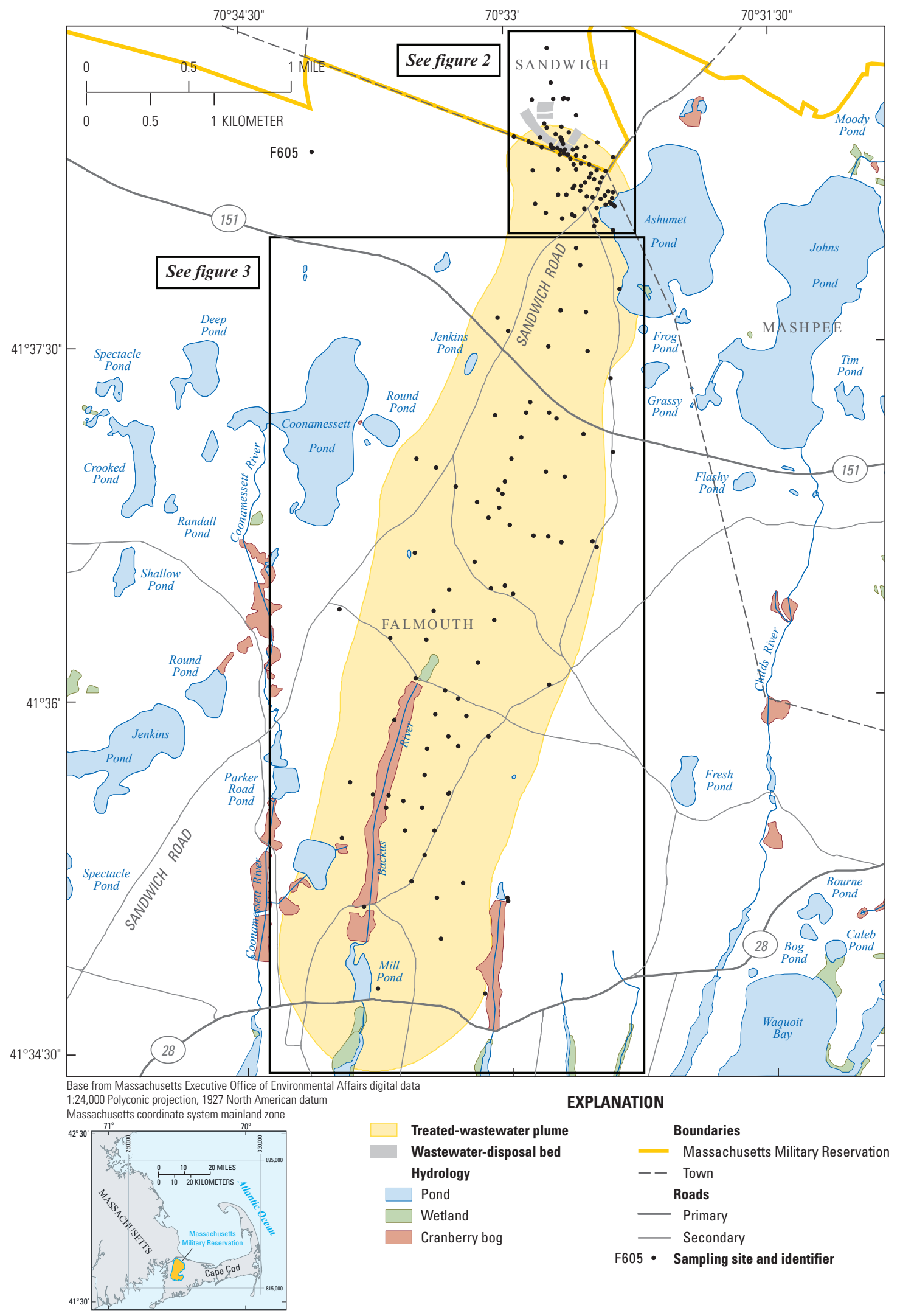

Figure 1. The study area with the locations of monitoring wells, multilevel samplers, and profile borings sampled in 2006-08, and the extent of the treated-wastewater plume in 2007, Ashumet Valley, Cape Cod, Massachusetts. The extent of the plume is defined by concentrations of nitrate-nitrogen, chloride, and boron greater than about 29, 170, and 0.56 micromoles per liter $(0.4,6.0$, and 0.006 milligrams per liter), respectively (J.R. Barbaro, U.S. Geological Survey, written commun., 2010). 
In an effort to document changes in groundwater quality after wastewater disposal was stopped in December 1995, the U.S. Geological Survey (USGS), with assistance from the Air Force Center for Engineering and the Environment (AFCEE), collected groundwater samples in 2006-08 near the abandoned rapid-infiltration beds and within and near the treatedwastewater plume (figs. 1-3). The samples were analyzed for field parameters (specific conductance, $\mathrm{pH}$, dissolved oxygen and phosphate concentrations, and alkalinity); absorbance of ultraviolet/visible light; concentrations of nitrous oxide, dissolved organic carbon, methylene blue active substances, selected anions and nutrients, including nitrate and ammonium, and selected inorganic solutes, including cations, anions, and minor elements.

This report compiles selected groundwater quality and water-level data that were collected as part of this study. The dataset includes water-quality data from monitoring wells, multilevel samplers (MLSs), and profile boring samples in the area that extends from about 2,000 $\mathrm{ft}$ upgradient of the former infiltration beds at monitoring-well cluster S315 (fig. 2) to the toe of the plume near Vineyard Sound at monitoringwell cluster F497 (fig. 3). Previous water-quality data for the treated-wastewater plume can be found in Thurman and others (1984), Savoie and LeBlanc (1998), and Savoie and others (2006). Findings from the first few years of monitoring after disposal to the rapid-infiltration beds ended have been presented elsewhere (Barber and Keefe, 1999; Campo and Hess, 1999; Kent and Maeder, 1999; LeBlanc and others, 1999; Smith and others, 1999). A comprehensive discussion of the effect of natural restoration on nitrogen and dissolved organic carbon (DOC) can be found in Repert and others (2006); on zinc contamination in Kent and others (2000); and on phosphate contamination in Parkhurst and others (2003). Other data, research projects, and reports related to the treatedwastewater plume can be found at the USGS Cape Cod Toxic Substances Hydrology Program Web site (U.S. Geological Survey, 2011).

In a separate effort not described in this report, AFCEE collected groundwater samples in 2007-09 from additional wells and profile borings in the area shown in figure 1 as part of investigations and monitoring of contaminant plumes that originated from a former fire-training area and a historical chemical spill. The results, which include concentrations of volatile organic compounds, are documented in AFCEE (2008), AFCEE (2010), and the 2006, 2007, and 2008 annual system performance and ecological impact monitoring (SPEIM) program reports for the Chemical Spill-10 and Ashumet Valley plumes (AFCEE, 2011).

\section{Monitoring Groundwater Quality in the Treated-Wastewater Plume}

Groundwater-quality samples included in this report were collected in 2007 from 394 monitoring wells (at 121 well-cluster locations) and 780 MLS ports (at 42 locations), and in 2006-08 from 306 profile-boring depth intervals (at 20 locations) (figs. 1-3). These sites were selected from a larger set of available sites so that the spatial distribution of the data from the selected sites was sufficient to define the steep geochemical gradients near the disposal beds, describe the distributions of nitrate and ammonium in the distal portions of the plume, and determine historical trends in water quality in the plume since the first comprehensive sampling in 1978 (LeBlanc, 1984). The well, MLS, and profile-boring installation and sampling methods are summarized below. The sampling protocols also are described in more detail in Savoie and LeBlanc (1998); Savoie and others (2006); U.S. Geological Survey (variously dated); and AFCEE (2009).

\section{Monitoring Wells}

The monitoring wells were installed by several methods, including hollow-stem-auger, drive-and-wash, sonic, and direct-push drilling. The wells are in clusters containing one to nine wells. Most of the wells (353 of 394) are constructed of 2.0-inch (in.)- or 2.5-in.-diameter polyvinyl chloride (PVC) well casing and slotted PVC screens. The screens of most wells (362 of 394) are 2 to $5 \mathrm{ft}$ long and have 0.010 -in. slots. Fifteen wells, including 12 small-diameter (0.62-in.) wells installed in the bottom of Ashumet Pond by using direct-push drilling, are constructed of steel well casing. These wells have 1- to 20 -ft-long stainless steel wirewound or slotted screens. Selected monitoring-well information is given in table 1.

\section{Multilevel Samplers}

The MLSs were installed by using hollow-stem-auger drilling. The MLSs are constructed with 15 color-coded polyethylene tubes (with a 0.25 -in. outside diameter and a 0.17 -in. inside diameter) within a 1.25-in.-diameter PVC casing. The color-coded tubes extend from the land surface, down the PVC casing, and out into the aquifer through holes drilled in the PVC at various depths. The bottom of each polyethylene tube, referred to as the sampling port, is open but screened with a fine nylon fabric. Water levels cannot be measured in the MLSs; the water levels at the MLS locations were estimated by interpolation between water levels measured in nearby monitoring wells (table 1). Selected MLS information is given in table 2 .

\section{Sample Collection from Wells and Multilevel Samplers}

Groundwater samples were collected from the 2.0-in.-diameter or larger monitoring wells by using a Keck SP-81 submersible pump fitted with Teflon tubing and an isolation packer or a Grundfos Redi-Flo2 submersible pump 


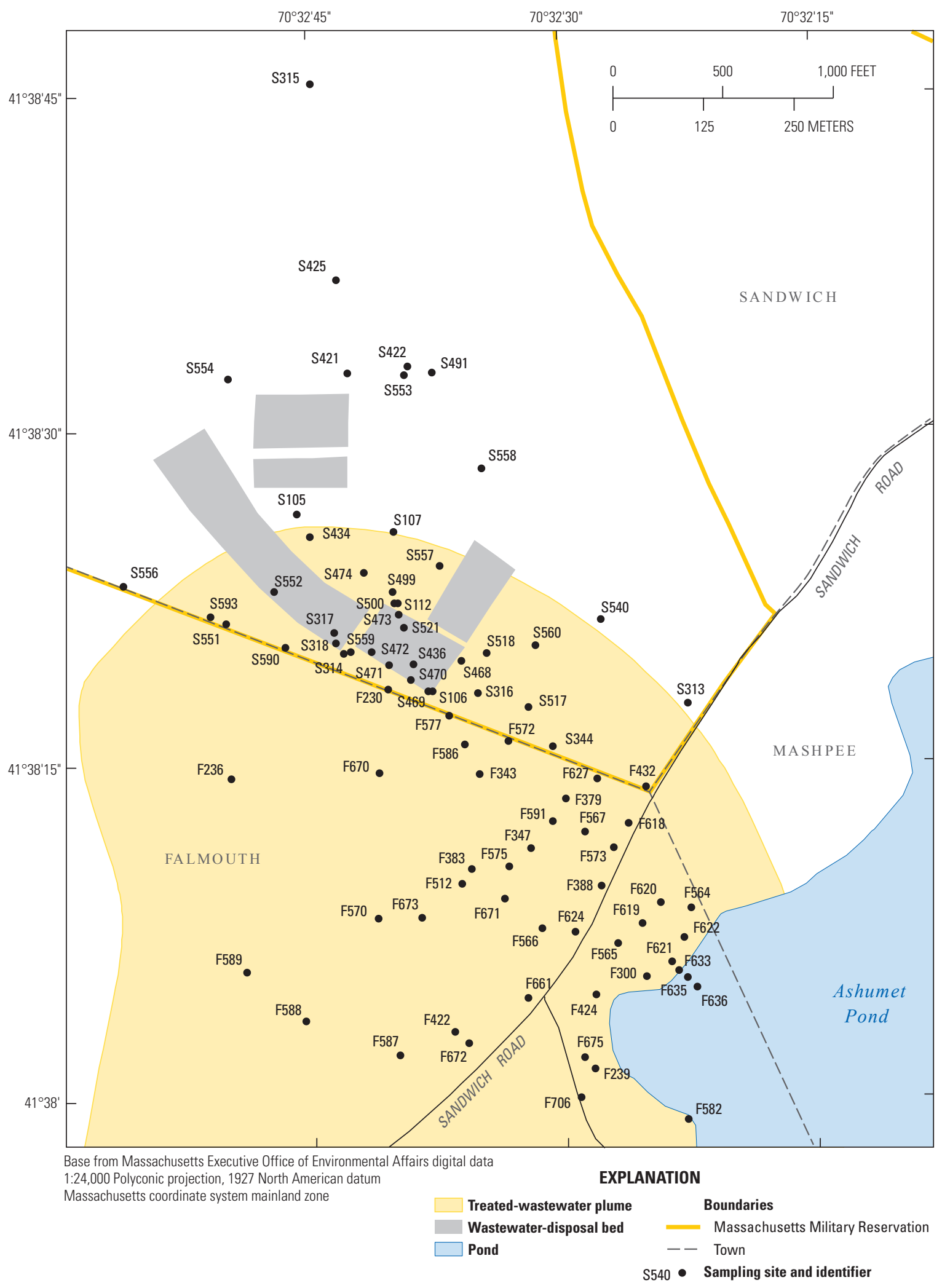

Figure 2. The portion of the study area extending from the wastewater-disposal beds at the Massachusetts Military Reservation to Ashumet Pond; the locations of monitoring wells, multilevel samplers, and profile borings sampled in 2006-08; and the extent of the treated-wastewater plume in 2007, Ashumet Valley, Cape Cod, Massachusetts. 


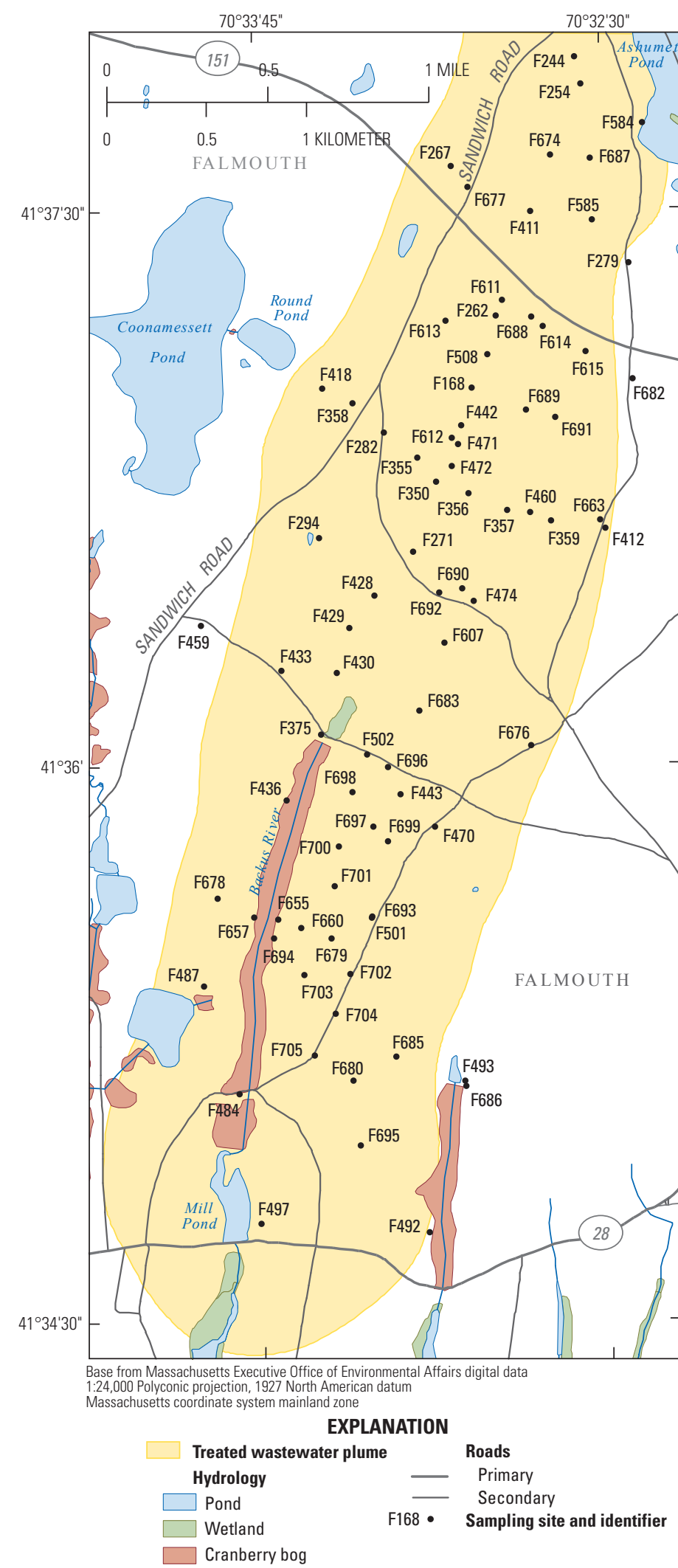

Figure 3. The portion of the study area extending from Ashumet Pond to Route 28; the locations of monitoring wells, multilevel samplers, and profile borings sampled in 2006-08; and the extent of the treated-wastewater plume in 2007, Ashumet Valley, Cape Cod, Massachusetts. fitted with Teflon-lined polyethylene tubing. The USGS and AFCEE used the Keck and Grundfos pumps, respectively. The Keck pump intake was generally set about $2 \mathrm{ft}$ above the top of the screen, and the packer was inflated to isolate the water in the casing above the packer from the pump intake. A minimum of three volumes of the casing below the packer was evacuated at a pumping rate of about 0.26 to 0.34 gallons per minute $(\mathrm{gal} / \mathrm{min})$ before field water-quality measurements were made and samples were collected. The Grundfos pump intake was set at the midpoint of the screened interval. A minimum of three volumes of the screened interval was evacuated at a pumping rate of about 0.026 to $0.53 \mathrm{gal} / \mathrm{min}$, and samples were collected only after field water-quality parameters had stabilized.

Groundwater samples were collected from the 0.62 - to 1.25 -in.-diameter wells by using a GeoPump2 peristaltic suction pump fitted with Norprene tubing that was connected to 0.25 -in.-diameter polyethylene tubing. The open end of the polyethylene tubing was set about $10 \mathrm{ft}$ below the static water level. A minimum of three casing volumes was evacuated at a pumping rate of about 0.26 to $0.53 \mathrm{gal} / \mathrm{min}$ before samples were collected. The 0.5 -in.-diameter temporary well (FSW 686-0010) was sampled by using a peristaltic pump connected directly to the driven casing.

Groundwater samples were collected from the MLSs by using a GeoPump2 peristaltic suction pump fitted with Norprene tubing that was connected directly to the MLS tubing. The pumping rate was about $0.079 \mathrm{gal} / \mathrm{min}$, and a minimum of three tubing volumes was evacuated before field water-quality measurements were made and water samples were collected.

\section{Sample Collection from Profile Borings}

The profile borings were drilled by direct-push and sonic methods (table 3). For the direct-push borings, a GeoProbe model 6620DT was used to advance 1.5-in.-diameter steel probe rods to each sampling interval sequentially; the bottom 5-ft-long rod was milled with 0.010 -in. slots. At each sampling interval, 0.5 -in.-diameter polyethylene tubing fitted with a Watera inertial-pump check valve was set into the slotted section at the bottom of the probe rods. Groundwater was pumped from the boring by using a reciprocating action; the pumping rate was highly dependent on depth to water and the aquifer material at the sampled interval, but generally was about 0.079 to $0.79 \mathrm{gal} / \mathrm{min}$. The pumped water tended to be turbid because of the surging caused by the reciprocating action. A minimum of three volumes of the probe rods was evacuated, and samples were collected only after field waterquality parameters had stabilized.

For the sonic borings, a Boart Longyear sonic drilling rig was used to advance a 7.68-in.-diameter steel casing to the bottom of the sampling interval. Water from a municipal water supply was pumped down the casing during drilling to prevent sediments from entering the casing. A 5-ft-long 
stainless steel wirewound screen attached to a 5.5-in.-diameter steel drill casing was lowered to the bottom of the boring, and the larger outer casing was pulled back about $5 \mathrm{ft}$ to expose the screen to the aquifer. A 4-in.-diameter submersible pump and packer assembly fitted to polyethylene tubing was lowered to just above the screen, and the packer was inflated to isolate the screened interval from the water in the casing above the screen. A minimum of three volumes of the casing below the packer was evacuated at a pumping rate of about 0.26 to $0.79 \mathrm{gal} / \mathrm{min}$, and water samples were collected after field water-quality parameters had stabilized.

\section{Field Water-Quality Measurements}

Field water-quality parameters for samples collected by the USGS were measured in unfiltered grab samples. The specific conductance was measured with a Thermo Orion model $130 \mathrm{~A}$ conductivity meter. The $\mathrm{pH}$ was measured with an Orion model 250A meter, an Orion Ross Sure-Flow model 81-72 pH electrode, and an Orion stainless steel, temperaturecompensating probe. Dissolved oxygen concentrations greater than $31 \mu \mathrm{M}$ were generally measured in samples collected in well flushed glass biological oxygen demand (BOD) bottles that were stoppered and chilled until measurement in the lab (within 6 hours of collection) with a YSI model 58 dissolved oxygen meter and YSI model 5905 probe. Dissolved oxygen concentrations less than $31 \mu \mathrm{M}$ were generally measured in the field by using a quantitative colorimetric method (CHEMetrics V-2000 photometer and K-7553 Vacu-vial self-filling reagent ampoules) with a practical detection limit of $3.1 \mu \mathrm{M}(0.10 \mathrm{mg} / \mathrm{L})(\mathrm{CHEMetrics}$, Inc., 2011). Phosphate also was measured colorimetrically in selected samples in the field (CHEMetrics VVR photometer, $\mathrm{K}-8513$ ampoules, and practical detection limit of $3.2 \mu \mathrm{M}\left(0.10 \mathrm{mg} / \mathrm{L} \mathrm{PO}_{4}\right.$ as $\left.\left.\mathrm{P}\right)\right)$. Temperature was measured by using the Orion stainless steel probe in conjunction with the $\mathrm{pH}$ probe. Turbidity was measured with a $\mathrm{HACH}$ model $2100 \mathrm{P}$ portable turbidimeter. Alkalinity was determined in the field for selected samples with expected elevated concentrations of iron(II) or in the laboratory for most samples by an incremental titration method (Fishman and Freidman, 1989) with the endpoint determined by using Gran plots. Iron concentrations were measured colorimetrically in selected samples in the field (CHEMetrics VVR photometer, K-6003 ampoules, and practical detection limit of $3.6 \mu \mathrm{M}(0.20 \mathrm{mg} / \mathrm{L}))$. The iron values were used only to check that the appropriate method was used to measure alkalinity. Most samples in which iron was detected also had concentrations that exceeded the method's maximum reporting level; for this reason, the fieldmeasured iron values are not presented in this report.

Field water-quality parameters for samples collected by AFCEE were measured by using a field YSI multiparameter model 6820 sonde. The parameters included specific conductance, $\mathrm{pH}$, dissolved oxygen concentration, turbidity, temperature, and oxidation-reduction potential. For samples collected from the monitoring wells and sonic profile borings, the sonde was placed in a flow-through chamber. For samples collected from the direct-push profile borings, the sonde was placed in a 1-L beaker filled with a grab sample because the flow rate generally was too low for use of the flow-through chamber. The dissolved oxygen concentrations were higher than expected for some samples, perhaps because of oxygen contamination during filling of the $1-\mathrm{L}$ beaker. The $\mathrm{pH}$ was also anomalously high for some samples, particularly the first few samples collected each day. Possible reasons include the persistent effects of the $\mathrm{pH} 7$ and 10 buffers used during calibration of the YSI sonde at the start of each day, and the large potential errors associated with $\mathrm{pH}$ measurements in poorly buffered, low-conductivity water unless rigorous procedures tailored to this geochemical condition are used (Busenberg and Plummer, 1987; Kent and Maeder, 1999). For these reasons, dissolved oxygen concentrations and $\mathrm{pH}$ measured with the YSI sonde in samples collected from the direct-push profiles are not included in this report. These data are available in the databases of the AFCEE Installation Restoration Program.

\section{Sample Preservation and Chemical Analysis}

Samples for analysis of absorbance of ultraviolet/ visible light, and concentrations of DOC, selected anions and nutrients, including nitrate and ammonium, and selected inorganic solutes, including cations, anions, and minor elements, were filtered through an inline polyvinylidene filter with a diameter of 33 millimeters $(\mathrm{mm})$ and a pore size of 0.45 micrometers $(\mu \mathrm{m})$ (Millipore Millex SLHV $033 \mathrm{NK}$ ). A new filter was used at each well, MLS port, or profile-boring interval. For samples that were especially turbid, an inline polysulfone disk filter with a pore size of $0.45 \mu \mathrm{m}$, polyester reinforcement, and an effective filtration area of 20 square centimeters $\left(\mathrm{cm}^{2}\right)$ was used instead (Pall AquaPrep 4270). The samples for analysis of selected inorganic solutes, including cations, anions, and minor elements, were preserved with trace-metal-grade nitric acid to a $\mathrm{pH}$ less than 2, the samples for analysis of ammonium were preserved with sulfuric acid to a $\mathrm{pH}$ less than 2 , and the samples for analysis of selected anions, including nitrate, were frozen. Filtered and unfiltered samples for analysis of methylene blue active substances (MBAS) by field photometer and commercial laboratory, respectively, were chilled. The nitrous oxide samples were collected by using a syringe and serum bottles that had been pretreated with potassium hydroxide, fitted with thick butyl rubber septa, and flushed with helium of ultra-high-purity grade for 15 minutes. The pumps and sampling equipment were decontaminated with laboratory-grade deionized water after each well or MLS had been sampled. This method for decontamination had been shown in other studies to be sufficient (Savoie and LeBlanc, 
1998). Samples of the deionized water (rinsewater blank) and the rinsewater from the Keck submersible pump (equipment rinsewater) were collected following the collection of groundwater samples from monitoring well FSW 355-0104. Duplicate analysis was performed on about 10 percent of the samples collected. At selected wells or MLS ports, an aliquot of the filtered sample was passed through a cartridge containing Chelex. Chelex is a cation exchanger that has a high selectivity for multivalent cations and therefore retains free metal ions while allowing strongly complexed metal ions to pass through (Kent and Maeder, 1999).

Concentrations of selected anions and and nutrients, DOC, and nitrous oxide were analyzed by the USGS National Research Program laboratory in Boulder, Colorado (Repert and others, 2006). The selected anions and nutrients, including nitrate, nitrite, and ammonium, were analyzed by using a flow-injection autoanalyzer and ion chromatography. DOC was converted to carbon dioxide by heated-persulfate oxidation, and concentrations were determined with infrared or conductivity detection. Concentrations of nitrous oxide were determined by gas chromatography after equilibration at $35^{\circ} \mathrm{C}$. Aqueous concentrations of the gas were calculated by using temperature-corrected Bunsen solubility coefficients. Concentrations of selected inorganic solutes, including cations, anions, and minor elements, were determined by using inductively coupled plasma atomic emission spectroscopy by the USGS National Research Program laboratory in Menlo Park, California. The descriptions of methods, limits of quantitation, precision, and accuracy for results of analyses for the selected inorganic solutes are described in Savoie and others (2004).

Concentrations of MBAS in replicate samples were analyzed by using a colorimetric method (method 425.1, U.S. Environmental Protection Agency, 1983). MBAS analysis is a measurement of total anionic surfactants, including linear- and branch-chained alkylbenzenesulfonates. Concentrations of MBAS were analyzed at the USGS office in Northborough, Massachusetts, several days after the samples were collected by using a CHEMetrics model I-2017 single analyte meter and R-9423 Vacu-vial self-filling reageant ampoules. The practical detection limit of the method is $0.25 \mathrm{mg} / \mathrm{L}$. Replicate samples for MBAS were analyzed by Test America, a commercial laboratory in Savannah, Georgia.

\section{Water-Quality Data}

Water samples collected in 2007 from 394 monitoring wells (at 121 well-cluster locations) and 780 MLS ports (at 42 locations) and in 2006-08 from 306 profile-boring depth intervals (at 20 locations) were analyzed for field waterquality parameters (table 4); concentrations of selected anions, ammonium, and nitrous oxide (table 5); concentrations of DOC and MBAS, and absorbance of ultraviolet/visible light (table 6); and concentrations of selected inorganic solutes, including cations, anions, and minor elements (table 7). Water samples collected in 2006-08 from 306 profile-boring depth intervals (at 20 locations) were analyzed for field water-quality parameters (table 8); concentrations of selected anions and ammonium (table 9); and concentrations of selected inorganic solutes, including cations, anions, and minor elements (table 10). Duplicate analyses for the analytes are included in the data tables and designated by "-D". Samples that were filtered through the Chelex filter are designated by " $X$ " in table 7 . Analyses of the rinsewater blank and equipment-rinsewater samples are shown at the bottoms of tables 5 and 7 .

The entries in the data tables are sorted by sampling site, which can include one or more wells and MLSs. The sites are shown in figures 2 and 3 with short labels that include only the first letter of the town code (for example, the label "MA-FSW" in the town of Falmouth is shown as "F"), followed by the three-digit sequential site number for that town. The tables list the sampling points at a site in order of descending altitude rather than in alphanumerical order so that the vertical distributions of concentrations and water-quality parameters are evident.

The temperature was measured at land surface in either a beaker along with the $\mathrm{pH}$ measurements or in a flow cell with the YSI sonde. The temperature measured by these methods may differ substantially from the temperature in the aquifer at the sampling point because of warming or cooling during passage of the water up the sample-collection tube and through the pump.

Lithium concentrations were below quantitation limits in all samples but are reported in tables 7 and 10 for completeness (the method used to develop the limits of quantitation for the inorganic solutes is described in Savoie and LeBlanc (1998)). Zinc concentrations less than $0.2 \mu \mathrm{M}$ in table 7 are subject to large random errors that may be related to contamination during sampling. The source of contamination was not identified.

The field water-quality data in table 8 for the profile borings made by using the direct-push method were commonly affected by turbid samples resulting from the reciprocating action of the inertial pump. The data also were affected by low pumping rates resulting from the small surface area open to the aquifer on the slotted steel probe rods and the difficulty of developing the slots to obtain greater yields. The high turbidity in some samples also may have affected the measurements made colorimetrically in the field for dissolved oxygen and phosphate concentrations. Because of the high turbidity, the generally challenging sampling environment during drilling operations, and the collection of samples directly from probe rods and drill casings made of steel, the profile-boring samples were not analyzed for minor elements such as iron, manganese, and boron. Despite these considerations, the borehole profiles provide valuable data on the vertical distributions of chemical parameters in areas of the plume that have few permanent sampling locations. 


\section{Summary}

During the period 2006-08, the U.S. Geological Survey and the Air Force Center for Engineering and the Environment collected groundwater samples from 394 wells, 780 multilevel-sampler ports, and 306 profileboring depth intervals in and near the treated-wastewater plume that originates from rapid-infiltration disposal beds at the Massachusetts Military Reservation, Cape Cod, Massachusetts. The beds were used for about 60 years ending in December 1995. The natural restoration of the sand and gravel aquifer as uncontaminated groundwater flushes through the area of the treated-wastewater plume is being studied by the U.S. Geological Survey. This report provides data to support research on the natural restoration of the plume and transport of contaminants such as nitrate and ammonium in the sand and gravel aquifer. The groundwater samples described in this report were collected from points in and adjacent to the 5-mi-long plume. The chemical data presented include field water-quality parameters (specific conductance, $\mathrm{pH}$, dissolved oxygen concentration, turbidity, temperature, and alkalinity); concentrations of selected anions and nutrients, including nitrate and ammonium, dissolved organic carbon, nitrous oxide, methylene blue active substances, and selected inorganic solutes, including cations, anions, and minor elements; and absorbance of ultraviolet/visible light.

\section{References Cited}

Abrams, R.H., and Loague, K., 2000, A compartmentalized solute transport model for redox zones in contaminated aquifers - 1 . Theory and development: Water Resources Research, v. 36, no. 8, p. 2001-2013.

Abrams, R.H., Loague, K., and Kent, D.B., 1998, Development and testing of a compartmentalized reaction network model for redox zones in contaminated aquifers: Water Resources Research, v. 34, no. 6, p. 1531-1541.

Air Force Center for Engineering and the Environment (AFCEE), 2008, Final Chemical Spill-10 2007 southern trench technical memorandum: AFCEE/Massachusetts Military Reservation, Installation Restoration Program, Otis Air National Guard Base, MA, MMR document no. 337105-SPEIM-CS10-TECHMEM-003, prepared by CH2M Hill, Inc., January 2008, variously paged.

Air Force Center for Engineering and the Environment (AFCEE), 2009, Quality assurance project plan for the MMR SPEIM/LTM/O\&M Program: AFCEE/Massachusetts Military Reservation, Installation Restoration Program, Otis Air National Guard Base, MA, MMR document no. 19059, 389849-Program-Multiple-QAPP-001, prepared by CH2M Hill, Inc., December 2009, variously paged.
Air Force Center for Engineering and the Environment (AFCEE), 2010, Final updated interim remedial action report for Chemical Spill-10 and Ashumet Valley groundwater plumes: AFCEE/Massachusetts Military Reservation, Installation Restoration Program, Otis Air National Guard Base, MA, prepared by ECC, Inc., August 2010, variously paged.

Air Force Center for Engineering and the Environment (AFCEE), 2011, Primary documents, Ashumet Valley and CS-10: AFCEE/Massachusetts Military Reservation, Installation Restoration Program, accessed February 5, 2011, at http://mmr.org/primarydocs/primarydocs.html.

Air Force Center for Environmental Excellence (AFCEE), 2005, Final Ashumet Valley axial 2003 annual system performance and ecological impact monitoring report: AFCEE/Massachusetts Military Reservation, Installation Restoration Program, 187615-SPEIM-ASH-ANRPT-002, variously paged.

Barber, L.B., II, 1998, Organic carbon fractionation and specific organic compounds, in Savoie, Jennifer, and LeBlanc, D.R., eds., Water-quality data and methods of analysis for samples collected near a plume of sewagecontaminated ground water, Ashumet Valley, Cape Cod, Massachusetts, 1993-94: U.S. Geological Survey WaterResources Investigations Report 97-4269, p. 16-19.

Barber, L.B., and Keefe, S.H., 1999, Evolution of a groundwater sewage plume after removal of the 60 -year-long source, Cape Cod, Massachusetts - Changes in the distribution of dissolved oxygen, boron, and organic carbon, in Morganwalp, D.W., and Buxton, H.T., eds., U.S. Geological Survey Toxic Substances Hydrology Program-Subsurface contamination from point sources: U.S. Geological Survey Water-Resources Investigations Report 99-4018C, Proceedings of the Technical Meeting, Charleston, South Carolina, March 8-12, 1999, v. 3, p. 261-270.

Barber, L.B., Keefe, S.H., LeBlanc, D.R., Bradley, P.M., Chapelle, F.H., Meyer, M.T., Loftin, K.A., Kolpin, D.W., and Rubio, Fernando, 2009, Fate of sulfamethoxazole, 4-nonylphenol, and 17ß-estradiol in groundwater contaminated by wastewater treatment plant effluent: Environmental Science \& Technology, v. 43, no. 13, p. 4843-4850.

Barber, L.B., II, Thurman, E.M., Schroeder, M.P., and LeBlanc, D.R., 1988, Long-term fate of organic micropollutants in sewage-contaminated groundwater: Environmental Science \& Technology, v. 22, no. 2, p. 205-211.

Böhlke, J.K., Smith, R.L., and Miller, D.N., 2006, Ammonium transport and reaction in contaminated groundwaterApplication of isotope tracers and isotope fractionation studies: Water Resources Research, v. 42, W05411, 19 p. 
Busenberg, Eurybiades, and Plummer, L.N., 1987, pH measurement of low-conductivity waters: U. S. Geological Survey Water-Resources Investigation Report 87-4060, $22 \mathrm{p}$.

Campo, K.W., and Hess, K.M., 1999, Evolution of a groundwater sewage plume after removal of the 60-year-long source, Cape Cod, Massachusetts - Fate of volatile organic compounds, in Morganwalp, D.W., and Buxton, H.T., eds., U.S. Geological Survey Toxic Substances Hydrology Program-Subsurface contamination from point sources: U.S. Geological Survey Water-Resources Investigations Report 99-4018C, Proceedings of the Technical Meeting, Charleston, South Carolina, March 8-12, 1999, v. 3, p. 271-284.

Ceazan, M.L., Thurman, E.M., and Smith, R.L., 1989, Retardation of ammonium and potassium transport through a contaminated sand and gravel aquifer-The role of cation exchange: Environmental Science \& Technology, v. 23, no. 11 , p. 1402-1408.

CHEMetrics, Inc., 2010, Self-filling ampoules for water analysis - Analytical methods: CHEMetrics, Inc., accessed April 15, 2011, at http://www.chemetrics.com/index. php?Page $=$ methods \& $t a b=2$.

Field, J.A., Barber, L.B., II, Thurman, E.M., Moore, B.L., Lawrence, D.L., and Peake, D.A., 1992, Fate of alkylbenzenesulfonates and dialkyltetralinsulfonates in sewage contaminated ground water: Environmental Science \& Technology, v. 26, no. 5, p. 1140-1148.

Fishman, M.J., and Friedman, L.C., eds., 1989, Methods for determination of inorganic substances in water and fluvial sediments: U.S. Geological Survey Techniques of WaterResources Investigations, book 5, chap. A1, 545 p.

Frimpter, M.H., and Gay, F.B., 1979, Chemical quality of ground water on Cape Cod, Massachusetts: U.S. Geological Survey Water-Resources Investigations Report 79-65, 11 p., 1 map in pocket.

Harvey, R.W., and Barber, L.B., II, 1992, Associations of freeliving bacteria and dissolved organic compounds in a plume of contaminated groundwater: Journal of Contaminant Hydrology, v. 9, no. 1-2, p. 91-103.

Harvey, R.W., and George, L.H., 1987, Growth determinations for unattached bacteria in a contaminated aquifer: Applied and Environmental Microbiology, v. 53, no. 12, p. 2992-2996.

Harvey, R.W., Smith, R.L., and George, Leah, 1984, Effect of organic contamination upon microbial distributions and heterotrophic uptake in a Cape Cod, Massachusetts, aquifer: Applied and Environmental Microbiology, v. 48, no. 6, p. 1197-1202.

Kent, D.B., Abrams, R.H., Davis, J.A., Coston, J.A., and LeBlanc, D.R., 2000, Modeling the influence of variable $\mathrm{pH}$ on the transport of zinc in a contaminated aquifer using semiempirical surface complexation models: Water Resources Research, v. 36, no. 12, p. 3411-3425.
Kent, D.B., Davis, J.A., Anderson, L.C.D., Rea, B.A., and Waite, T.D., 1994, Transport of chromium and selenium in the suboxic zone of a shallow aquifer-Influence of redox and adsorption reactions: Water Resources Research, v. 30, no. 4, p. 1099-1114.

Kent, D.B., and Fox, P.M., 2004, The influence of groundwater chemistry on arsenic concentrations and speciation in a quartz sand and gravel aquifer: Geochemical Transactions, v. 5, no. 1, p. 1-12.

Kent, D.B., and Maeder, V., 1999, Evolution of a ground-water sewage plume after removal of the 60-year-long source, Cape Cod, Massachusetts - $\mathrm{pH}$ and the fate of phosphate and metals, in Morganwalp, D.W., and Buxton, H.T., eds., U.S. Geological Survey Toxic Substances Hydrology Program - Subsurface contamination from point sources: U.S. Geological Survey Water-Resources Investigations Report 99-4018C, Proceedings of the Technical Meeting, Charleston, South Carolina, March 8-12, 1999, v. 3, p. 293-304.

Kinner, N.E., Harvey, R.W., Blakeslee, K., Novarino, G., and Meeker, L.D., 1998, Size-selective predation of groundwater bacteria by nanoflagellates in an organiccontaminated aquifer: Applied and Environmental Microbiology, v. 64, no. 2, p. 618-625.

Kinner, N.E., Harvey, R.W., and Kazmierkiewicz-Tabaka, Marina, 1997, Effect of flagellates on free-living bacterial abundance in an organically contaminated aquifer: Federation of European Microbiological Societies (FEMS) Microbiology Reviews, v. 20, no. 3-4, p. 249-259.

Kinner, N.E., Harvey, R.W., Shay, D.M., Metge, D.M., and Warren, Alan, 2002, Field evidence for a protistan role in an organically-contaminated aquifer: Environmental Science \& Technology, v. 36, no. 20, p. 4312-4318.

LeBlanc, D.R., 1984, Sewage plume in a sand and gravel aquifer, Cape Cod, Massachusetts: U.S. Geological Survey Water-Supply Paper 2218, 28 p.

LeBlanc, D.R., Guswa, J.H., Frimpter, M.H., and Londquist, C.J., 1986, Ground-water resources of Cape Cod, Massachusetts: U.S. Geological Survey Hydrologic Atlas 692, 2 maps, 2 data sheets.

LeBlanc, D.R., Hess, K.M., Kent, D.B., Smith, R.L., Barber, L.B., Stollenwerk, K.G., and Campo, K.W., 1999, Natural restoration of a sewage plume in a sand and gravel aquifer, Cape Cod, Massachusetts, in Morganwalp, D.W., and Buxton, H.T., eds., U.S. Geological Survey Toxic Substances Hydrology Program-Subsurface contamination from point sources: U.S. Geological Survey WaterResources Investigations Report 99-4018C, Proceedings of the Technical Meeting, Charleston, South Carolina, March 8-12, 1999, v. 3, p. 245-259.

Lee, R.W., and Bennett, P.C., 1998, Reductive dissolution and reactive solute transport in a sewage-contaminated glacial outwash aquifer: Ground Water, v. 36, no. 4, p. 583-595. 
McCobb, T.D., LeBlanc, D.R., Walter, D.A., Hess, K.M., Kent, D.B., and Smith, R.L., 2003, Phosphorus in a groundwater contaminant plume discharging to Ashumet Pond, Cape Cod, Massachusetts, 1999: U.S. Geological Survey Water-Resources Investigations Report 02-4306, 69 p.

Metge, D.W., Brooks, M.H., Smith, R.L., and Harvey, R.W., 1993, Effect of treated-sewage contamination upon bacterial energy charge, adenine nucleotides, and DNA content in a sandy aquifer on Cape Cod: Applied and Environmental Microbiology, v. 59, no. 7, p. 2304-2310.

Parkhurst, D.L., Stollenwerk, K.G., and Colman, J.A., 2003, Reactive-transport simulation of phosphorus in the sewage plume at the Massachusetts Military Reservation, Cape Cod, Massachusetts: U.S. Geological Survey WaterResources Investigations Report 03-4017, 33 p.

Repert, D.A., Barber, L.B., Hess, K.M., Keefe, S.H., Kent, D.B., LeBlanc, D.R., and Smith, R.L., 2006, Longterm natural attenuation of carbon and nitrogen within a groundwater plume originating from treated wastewater: Environmental Science \& Technology, v. 40, no. 4, p. 1154-1162.

Savoie, Jennifer, and LeBlanc, D.R., 1998, Water-quality data and methods of analysis for samples collected near a plume of sewage-contaminated ground water, Ashumet Valley, Cape Cod, Massachusetts, 1993-94: U.S. Geological Survey Water-Resources Investigations Report 97-4269, $208 \mathrm{p}$.

Savoie, J.G., Kent, D.B., Smith, R.L., LeBlanc, D.R., and Hubble, D.W., 2004, Changes in ground-water quality near two granular-iron permeable reactive barriers in a sand and gravel aquifer, Cape Cod, Massachusetts, 1997-2000: U.S. Geological Survey Water-Resources Investigations Report 03-4309, 11 p.

Savoie, J.G., Smith, R.L., Kent, D.B., Hess, K.M., LeBlanc, D.R., and Barber, L.B., 2006, Ground-water-quality data for a treated-wastewater plume undergoing natural restoration, Ashumet Valley, Cape Cod, Massachusetts, 1994-2004: U.S. Geological Survey Data Series 198, 1 CD-ROM.

Smith, R.L., Böhlke, J.K., Garabedian, S.P., Revesz, K.M., and Yoshinari, Tadashi, 2004, Assessing denitrification in groundwater using natural gradient tracer tests with ${ }^{15} \mathrm{~N}$ - In situ measurement of a sequential multistep reaction: Water Resources Research, v. 40, W07101, 17 p.

Smith, R.L., and Duff, J.H., 1988, Denitrification in a sand and gravel aquifer: Applied and Environmental Microbiology, v. 54, no. 5, p. 1071-1078.

Smith, R.L., Harvey, R.W., and LeBlanc, D.R., 1991a, Importance of closely spaced vertical sampling in delineating chemical and microbiological gradients in groundwater studies: Journal of Contaminant Hydrology, v. 7, no. 3 , p. 285-300.
Smith, R.L., Howes, B.L., and Duff, J.H., 1991b, Denitrification in nitrate-contaminated ground waterOccurrence in steep vertical geochemical gradients: Geochimica et Cosmochimica Acta, v. 55, no. 7, p. 1815-1825.

Smith, R.L., Rea Kumler, B.A., Peacock, T.R., and Miller, D.N., 1999, Evolution of a ground-water sewage plume after removal of the 60-year-long source, Cape Cod, Massachusetts-Inorganic nitrogen species, in Morganwalp, D.W., and Buxton, H.T., eds., U.S. Geological Survey Toxic Substances Hydrology Program-Subsurface contamination from point sources: U.S. Geological Survey WaterResources Investigations Report 99-4018C, Proceedings of the Technical Meeting, Charleston, South Carolina, March 8-12, 1999, v.3, p. 285-292.

Stollenwerk, K.G., 1996, Simulation of phosphate transport in sewage-contaminated groundwater, Cape Cod, Massachusetts: Applied Geochemistry, v. 11, no. 1-2, p. 317-324.

Thurman, E.M., Barber, L.B., II, Ceazan, M.L., Smith, R.L., Brooks, M.G., Schroeder, M.P., Keck, A.J., Driscoll, A.J., LeBlanc, D.R., and Nichols, W.J., Jr., 1984, Sewage contaminants in ground water, in LeBlanc, D.R., ed., Movement and fate of solutes in a plume of sewagecontaminated ground water, Cape Cod, MassachusettsU.S. Geological Survey Toxic Waste Ground-Water Contamination Program: U.S. Geological Survey Open-File Report 84-475, Toxic Waste Technical Meeting, Tucson, Arizona, March 20-22, 1984, p. 47-88.

Thurman, E.M., Barber, L.B., Jr., and LeBlanc, D.R., 1986, Movement and fate of detergents in groundwater-A field study: Journal of Contaminant Hydrology, v. 1, no. 1, p. 143-161.

U.S. Geological Survey, 2011, Cape Cod Toxic-Substances Hydrology research site, Toxic Substances Hydrology Program, accessed February 9, 2012, at http://ma.water. usgs.gov/MMRCape.

U.S. Geological Survey, variously dated, National field manual for the collection of water-quality data: U.S. Geological Survey Techniques of Water-Resources Investigations, book 9, chaps. A1-A9.

U.S. Environmental Protection Agency, 1983, Methods for chemical analysis of water and wastes: U.S. Environmental Protection Agency publication no. 600/4-79/020, 491 p.

Walter, D.A., Rea, B.A., Stollenwerk, K.G., and Savoie, Jennifer, 1996, Geochemical and hydrologic controls on phosphorus transport in a sewage-contaminated sand and gravel aquifer near Ashumet Pond, Cape Cod, Massachusetts: U.S. Geological Survey Water-Supply Paper 2463, 89 p. 


\section{Tables}

Click on link to view tables

1. Location coordinates, land-surface and screen altitudes, well diameters, casing and screen materials, and waterlevel altitudes and measurement dates for monitoring wells, Ashumet Valley treated-wastewater plume, Cape Cod, Massachusetts [Click here]

2. Location coordinates, land-surface and screen altitudes, and estimated water-table altitudes for multilevel samplers, Ashumet Valley treated-wastewater plume, Cape Cod, Massachusetts [Click here]

3. Drilling method, location coordinates, altitudes of land surface and tops and bottoms of sampling intervals, and estimated altitudes of the water table for direct-push and sonic profile borings, Ashumet Valley treated-wastewater plume, Cape Cod, Massachusetts, 2006-08 [Click here]

4. Field water-quality analyses for groundwater samples collected from wells and multilevel samplers, Ashumet Valley treated-wastewater plume, Cape Cod, Massachusetts, 2007 [Click here]

5. Concentrations of selected anions, ammonium, and nitrous oxide in groundwater samples collected from wells and multilevel samplers, Ashumet Valley treated-wastewater plume, Cape Cod, Massachusetts, 2007 [Click here]

6. Ultraviolet/visible light absorbance and concentrations of dissolved organic carbon and methylene blue active substances in groundwater samples collected from wells and multilevel samplers, Ashumet Valley treated-wastewater plume, Cape Cod, Massachusetts, 2007 [Click here]

7. Concentrations of selected inorganic solutes, including cations, anions, and minor elements, in groundwater samples collected from wells and multilevel samplers, Ashumet Valley treated-wastewater plume, Cape Cod, Massachusetts, 2007 [Click here]

8. Field water-quality analyses for groundwater samples collected from direct-push and sonic profile borings, Ashumet Valley treated-wastewater plume, Cape Cod, Massachusetts, 2006-08 [Click here]

9. Concentrations of selected anions and ammonium in groundwater samples collected from direct-push and sonic profile borings, Ashumet Valley treated-wastewater plume, Cape Cod, Massachusetts, 2006-08 [Click here]

10. Concentrations of selected inorganic solutes, including cations, anions, and minor elements, in groundwater samples collected from direct-push and sonic profile borings, Ashumet Valley treated-wastewater plume, Cape Cod, Massachusetts, 2006-08 [Click here] 
This page has been left blank intentionally. 
Prepared by the Pembroke Publishing Service Center.

For more information concerning this report, contact:

Director

U.S. Geological Survey

Massachusetts-Rhode Island Water Science Center 10 Bearfoot Road,

Northborough, MA 01532

dc_ma@usgs.gov

or visit our Web site at

http://ma.water.usgs.gov 
总

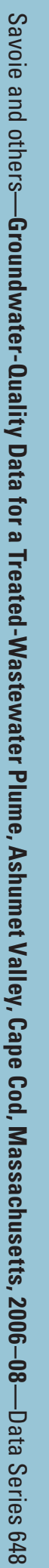

